\title{
Occurrences and genesis of palygorskite/ sepiolite and associated minerals in the Barzaman formation, United Arab Emirates
}

\author{
SALAH DRAIDIA ${ }^{1,2, *}$, MERIAM EL OUAHABI ${ }^{2}$, LAHCEN DAOUDI $^{3}$, \\ HANS-BALDER HAVENITH ${ }^{1}$ AND NATHALIE FAGEL ${ }^{2}$ \\ ${ }^{I}$ Department of Geology, Géorisques et Environnement, University of Liège, Liège, Belgium \\ ${ }^{2}$ Department of Geology, AGEs, University of Liège, Liège, Belgium \\ ${ }^{3}$ Department of Geology, Laboratory of Geosciences and Environment, University of Cadi Ayaad, Marrakech, Morocco
}

(Received 24 February 2016; revised 17 August 2016; Associate Editor: Martine Buatier)

\begin{abstract}
The Barzaman Formation exposed in the United Arab Emirates was deposited as a series of fluvial sediment sequences lying along the western margin of the Hajar Mountains, part of the Oman-UAE ophiolite. This formation consists of a sequence of rocks dominated by variably cemented and altered conglomerates comprising calcareous siltstones and calcareous clays deposited during the Miocene to Pliocene under a humid climate. The conglomerates are composed largely of ultramafic and lesser-mafic clasts. The present study was undertaken in order to understand the occurrence and genesis of palygorskite and sepiolite in relation to the environmental changes including evaporitic and sabkha environments.

Sediments were collected from two trenches and a drill hole of $\sim 22 \mathrm{~m}$ depth. Samples were analysed by optical petrograpy, X-ray diffraction and scanning electron microscopy. Pedogenesis occurred at the deeper level in well cemented conglomerate which constitutes the hard crust. Post-depositional erosion started in marine phreatic or vadose zones as shown by the neoformation of serpentine from the weathering of olivine as well as of calcite and dolomite. Neoformation of palygorskite, sepiolite, dolomite and halite occurred under evaporitic conditions on calcareous silty clay facies. Relatively hot, vadose and oxidizing environmental conditions affected the calcareous siltstone facies leading to the genesis of dolomite and palygorskite by direct precipitation from solution rich in $\mathrm{Ca}, \mathrm{Mg}, \mathrm{Al}, \mathrm{Fe}$ and Si ions.
\end{abstract}

KEYwORDS: Dubai, palygorskite/sepiolite, neoformation, pedogenesis, mineralogy, sabkha environnent.

Palygorskite and sepiolite are fibrous clay minerals typically formed in dry and warm climates at specific $\mathrm{pH}$ and concentrations of dissolved $\mathrm{SiO}_{2}$ (Isphording, 1973; Badraoui et al., 1992; Daoudi, 2004; Hillier \& Pharande, 2008; Knidiri et al., 2014). The authigenic formation of sepiolite and palygorskite requires alkaline solutions with high $\mathrm{Si}$ and $\mathrm{Mg}$ activities (Golden et al., 1985; Birsoy, 2002; Hong et al., 2007). Lacustrine and

*E-mail: sdraidia@ulg.ac.be https://doi.org/10.1180/claymin.2016.051.5.06 lagoonal environments favour the authigenic formation of these fibrous clays (Singer, 1979; Chamley, 1989). The importance of palygorskite and sepiolite as indicators of a seasonal semi-arid/arid climate has been recognized in the past (Chamley, 1989). These conditions occurred over time intervals such as the Early Maastrichtian-Eocene (Callen, 1984; Chamley, 1989).

In the Arabian plain (southern west Dubai), sepiolite and palygorskite occur in the Miocene to Pliocene sections of the Brazaman Formation, which comprises a thick succession of fluvial sediments characterized by poorly sorted conglomerate (Macklin et al., 2012; 
Lacinska et al., 2014). Tertiary rocks are found occasionally as an evaporate sequence comprising dolomitic limestone overlain by interbedded red sandstone, sandy limestone, marl with gypsum and mudstone (Macklin et al., 2012). The evaporitic sequence consists of an extensive palaeo-bajada that progrades out along the margins of the Hajar Mountains into an extension of the Zagros foreland basin (Fig. 1). These rocks, now extensively transformed to dolomite and palygorskite, represent the youngest part of the

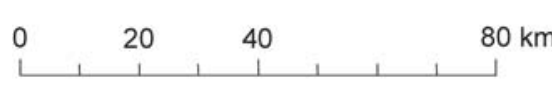

\section{Legend}

International boundary
Coast

Geology 250k

Simplified

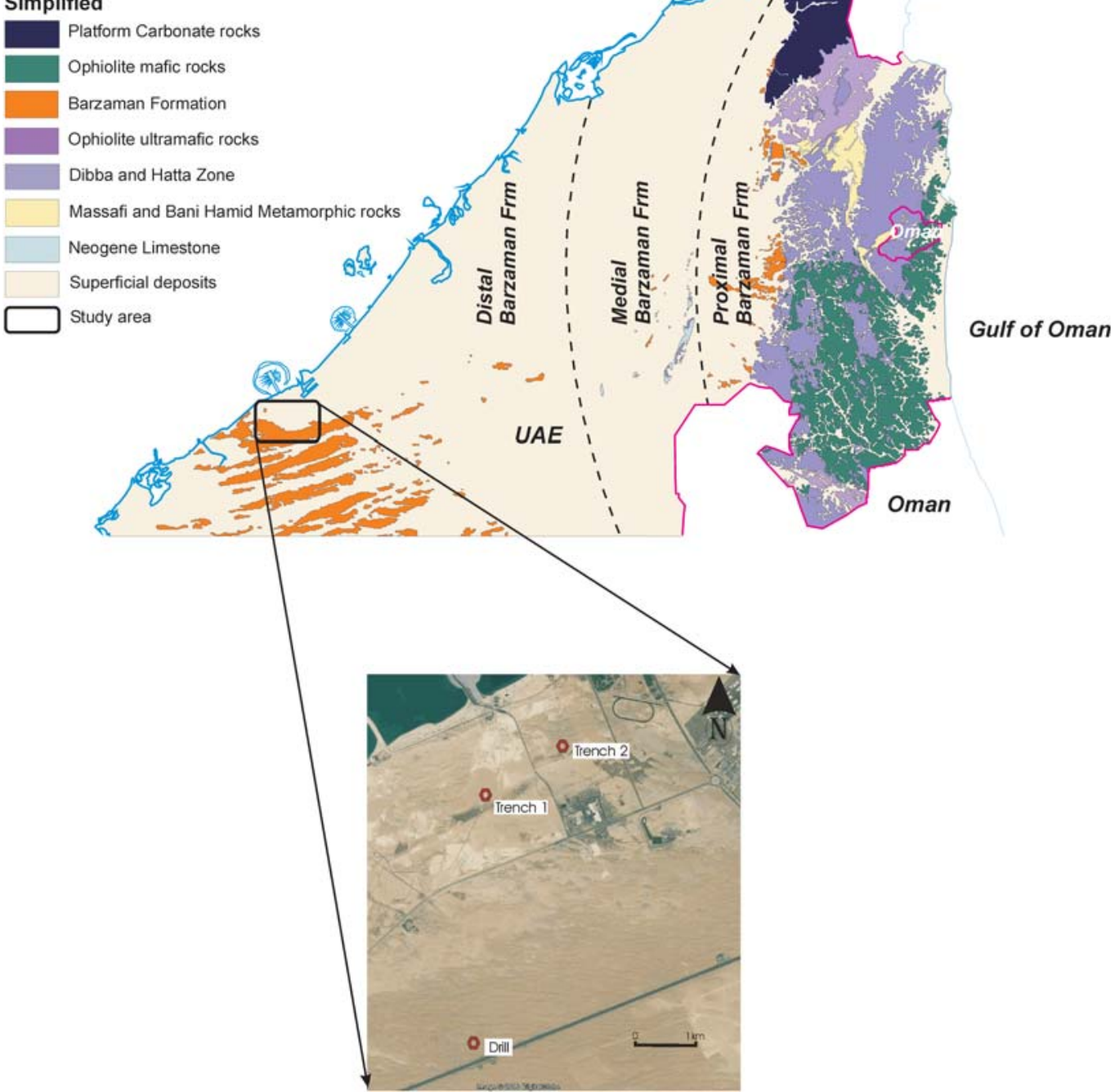

FIG. 1. Geology and geomorphology of the study area (reproduced from Lacinska et al., 2014, under permit number CP16/082 from the British Geological Survey (C NERC 2016. All rights reserved). The Google Earth image shows the location of the two trenches and the drill. 
Miocene foreland basin succession (Macklin et al., 2012). There is no biostratigraphical control for the age of the Barzaman Formation in the United Arab Emirates (UAE), whereas in Oman it has been established to have been formed during the Middle Miocene-Pliocene (Béchennec et al., 1993), consistent with observations made in the UAE (Farrant et al., 2012).

Post-depositional modifications affected the Brazaman Formation, diagenetic alteration and pedogenic processes over repeated climatic cycles throughout the Mio-Pliocene in particular. These modifications are shown by cementation, soil and crust formation (Macklin et al., 2012; Lacinska et al., 2014). The succession of uplift and erosion of the Oman Mountains provided the ophiolitic sediment inflow through the channels and outwashed plains during humid climatic conditions. During the arid conditions, significant evaporation and mobilization of carbonates provided cementation thereby modifying the original deposit.

According to Lacinska et al. (2014), three parts can be distinguished in the Brazaman Formation with respect to the proximity to the ophiolitic Hajar Mountains (Fig. 1). The present study is concerned with an area in the coastal region of Dubai, located in the distal part of the Barzaman Formation. This paper presents mineralogical and textural features related to diagenesis and pedogenesis processes in the distal Barzaman Formation, with special focus on the sabkha and lagoonal environment.

\section{GEOLOGICAL SETTING}

The geological history of the northern Emirates has been dominated by transgression and regression of the sea and the associated deposition of sediments during the postCambrian (Kiessling et al., 2003). Palaeozoic sediments are not exposed extensively and consist predominantly of shales and siltstones. Mesozoic deposits are represented by Jurassic to late Cretaceous limestone and dolomite. These deposits form the main reservoir rock for UAE oil reserves (Alsharhan et al., 2014). Their depositional environment is thought to be similar to the conditions prevailing today as they include sabkha-type deposits (Lokier, 2013). The lack of early Mesozoic and Tertiary sediments in the northern Emirates reflects the regression in those periods. Post-Cretaceous uplift has produced topographic highs such as Jebel Ali and Jebel Dhana, as well as offshore islands such as Das and Zirku (Boote et al., 1990). The most recent sea-level changes during the Pleistocene glaciations and the associated climate changes have given rise to many of the superficial sediments that cover the older rocks (Vine, 1996).
The northern Emirates consist of three present-day geological environments consisting of the Hajar Mountains, the desert and the sabkha deposits (Vine, 1996) (Fig. 1). The geology of the UAE has been influenced considerably by the deposition of marine sediments associated with numerous sea-level changes during recent geological time. Except for the ophiolitic mountains, shared with Oman in the northeast, the country is relatively low-lying with near-surface geology dominated by mobile aeolian dune sands and sabkha from Quaternary to late Pleistocene. The evaporite deposits are situated mostly in the northern coastal margin of the UAE. This environment is characterized by a high water table with occasionally flooded land. The dune deposits typically comprise fine-grained sand, silty sand and calcareous sand, with the latter being variably cemented. The degree of cementation generally increases with depth, exhibiting variably cemented sand in the shallow part whilst the deeper part is predominantly calcareous sandstone. In the near-shore coastal zone the superficial deposits are relatively thin and typically made of shelly and silty sands (Styles et al., 2006).

The Barzaman Formation was formed as a result of enhanced erosion following the uplift of the ophiolitedominated Hajar Mountains during the Late Miocene Zagros orogeny. In the coastal margin of Dubai the Distal Barzaman Formation facies (DBF) occurs; this lies several $\mathrm{km}$ out in the foreland basin around Dubai and Jebal Ali (Macklin et al., 2012). It consists of strongly altered, ophiolite-derived conglomerates, sandstones and siltstones which have been altered to dolostone and calcite-mudstone (50-90\% of calcite or dolomite-rich), preserved in a series of fining-upwards sequences (Micheels et al., 2007; Farrant et al., 2012). The conglomerate varies laterally across the site with localized channels; in some sections, up to six brown conglomerate horizons have been identified (Lacinska et al., 2014). Four key facies were identified and are described below.

\section{MATERIALS AND METHODS}

\section{Materials}

The study area is located $\sim 2 \mathrm{~km}$ from the shoreline near the Jebal Ali region (Dubai) corresponding to the distal part of the Barzaman Formation. Two trenches and a drill hole were sampled in the distal facies of the Barzaman Formation situated between 2 and $5 \mathrm{~km}$ from the shoreline, indicated in the geological map as a single unit which is beach sand (Fig. 1). 
A trench from the top soil down to a depth of $4.5 \mathrm{~m}$ (Trench1) was investigated and featured an homogeneous, fine-grained calcareous siltstone layer. Five samples, labelled CH4, CH4.12, CH4.25, CH4.36 and CH4.5 were collected at depths of 4, 4.12, 4.25, 4.36 and $4.5 \mathrm{~m}$, respectively (Fig. 2a).

A second trench, $7 \mathrm{~m}$ deep (Trench2) which was dug $\sim 1 \mathrm{~km}$ from Trench1 shows the following facies from top to bottom (Fig. 2): a brown to light-brown silty, partially cemented sand layer, from the top soil to a depth of $3 \mathrm{~m}$, followed by a fine to medium laminated, partially weathered calcarenite extending from a depth of 3 to $5.5 \mathrm{~m}$, then by a karstic silty sand containing, in places, soft clay-filled cavities from a depth of 5.5 to $6.5 \mathrm{~m}$ and finally by a calcareous gypsiferous clay (CGC) mostly indurated with crystalline gypsum and rounded gravel rock fragments extending from 6.5 to $7 \mathrm{~m}$ with off-white, greenish- or pinkish-coloured facies. Five samples labelled MT1, MQ1, MQ2, MQ3 and gypsum clay (GC) were collected from the CGC horizon of the trench, which seemed to be the most clay-rich sample. A sampling resolution of $\sim 40 \mathrm{~m}$ between adjacent samples was used (Fig. 2). An additional sample labelled karstic clay (KC) was collected at a depth of $\sim 6 \mathrm{~m}$ from a cavity in the karstic sandy layer for further investigation (Fig. 2).

A drill hole $\sim 22 \mathrm{~m}$ deep was made a few $\mathrm{km}$ to the landward side (Fig. 1). Calcareous silty sand with occasional gravels occur from the topsoil down to $1.8 \mathrm{~m}$ (Fig. 2a), followed by weakly cemented conglomerate with medium gravels and gypsum fragments down to $6.3 \mathrm{~m}$. Further down, to a depth of $8.3 \mathrm{~m}$, a weathered calcareous siltstone with gravels occurs. A weakly cemented conglomerate with fine to medium gravels extends from 8.3 to $10.9 \mathrm{~m}$ followed by a slightly weathered calcareous siltstone down to $13.8 \mathrm{~m}$. Subsequently, a succession of weakly cemented conglomerates, with fine- to medium-sized gravels and a weathered calcareous siltstone with gravels, was observed at 13.8-14.8 $\mathrm{m}$ and $14.8-19.4 \mathrm{~m}$, respectively. Finally, the lowest section, at 19.4-22 m, consists of weakly cemented conglomerate containing fine- to medium-sized gravels. Four samples, labelled Sb15, $\mathrm{Sb} 17, \mathrm{Sb} 19$ and Sb20, were collected at depths of 15, 17, 19 and $20 \mathrm{~m}$, respectively. For further investigation of the hard crust level, four other samples (R1, R3, Q3 and Q1A) were taken at depths ranging from 20.5 to $22 \mathrm{~m}$.

\section{Methods}

The mineralogical analysis was performed at the University of Liège, Belgium by means of X-ray diffraction (XRD), carried with a Bruker D8-Advance diffractometer, using $\mathrm{Cu}-\mathrm{K} \alpha$ radiation on powdered bulk sediment and on the $<2 \mu \mathrm{m}$ clay fraction. For bulk-sediment analysis, the relative abundance of minerals was estimated from the height of the main peak multiplied by the correction factors proposed by Cook et al. (1975). For analysis of the clay fraction, the entire sample was treated with $\mathrm{HCl}(0.1 \mathrm{~mol} / \mathrm{L})$ to dissolve carbonates and the $<2 \mu \mathrm{m}$ fraction was separated by settling in a water column. Samples were mounted as oriented aggregates on glass slides (Moore \& Reynolds, 1997). For each sample, three XRD patterns were recorded: air-dried $(\mathrm{N})$, ethyleneglycol solvated for $24 \mathrm{~h}(\mathrm{EG})$ and heated at $500^{\circ} \mathrm{C}$ for $4 \mathrm{~h}(\mathrm{H})$. The background noise of the XRD patterns was removed and the line position and the peak intensity was calculated using the DIFFRACplus EVA software (provided by Bruker). Semi-quantitative estimations of the main clay species were obtained on EG runs according to Biscaye (1965).

Nine thin sections $(60 \times 90 \mathrm{~mm})$ were cut from the drill samples and impregnated with epoxy resin to avoid warming. In addition, six of the samples were covered with Canada balsam. The thin sections were scanned and analysed using optical and binocular microscopes to characterize the sedimentary components and the matrix in order to evaluate the depositional environment. The analyses were performed at the Department of Geology, University of Liège, Belgium.

Scanning electron microscope (SEM) observations were performed at the Department of Chemistry, University of Liège, Belgium. According to the XRD results, seven clay-rich samples were prepared for SEM observation (KC and GC from Trench2, Ch4.36 from Trench1 and Sb17, Sb19, R1 and R3 from the Drill hole). The samples were partially polished, vacuum dried at $150^{\circ} \mathrm{C}$ for $6 \mathrm{~h}$, left overnight at $150^{\circ} \mathrm{C}$ in air, and finally gold coated for $40 \mathrm{~s}(350 \AA$ thick Au film) using a Giko ion coater.

\section{RESULTS}

\section{Mineralogical composition}

The bulk mineralogical compositions of the selected samples from the Trench1, Trench2 and drill hole are summarized in Table 1 and Fig. 2. The XRD analysis of disoriented powders showed variable compositions of the samples, although consisting predominantly of carbonates (calcite and dolomite in variable mixtures) and clay minerals. Quartz, feldspar and gypsum were present in small amounts and trace amounts of 

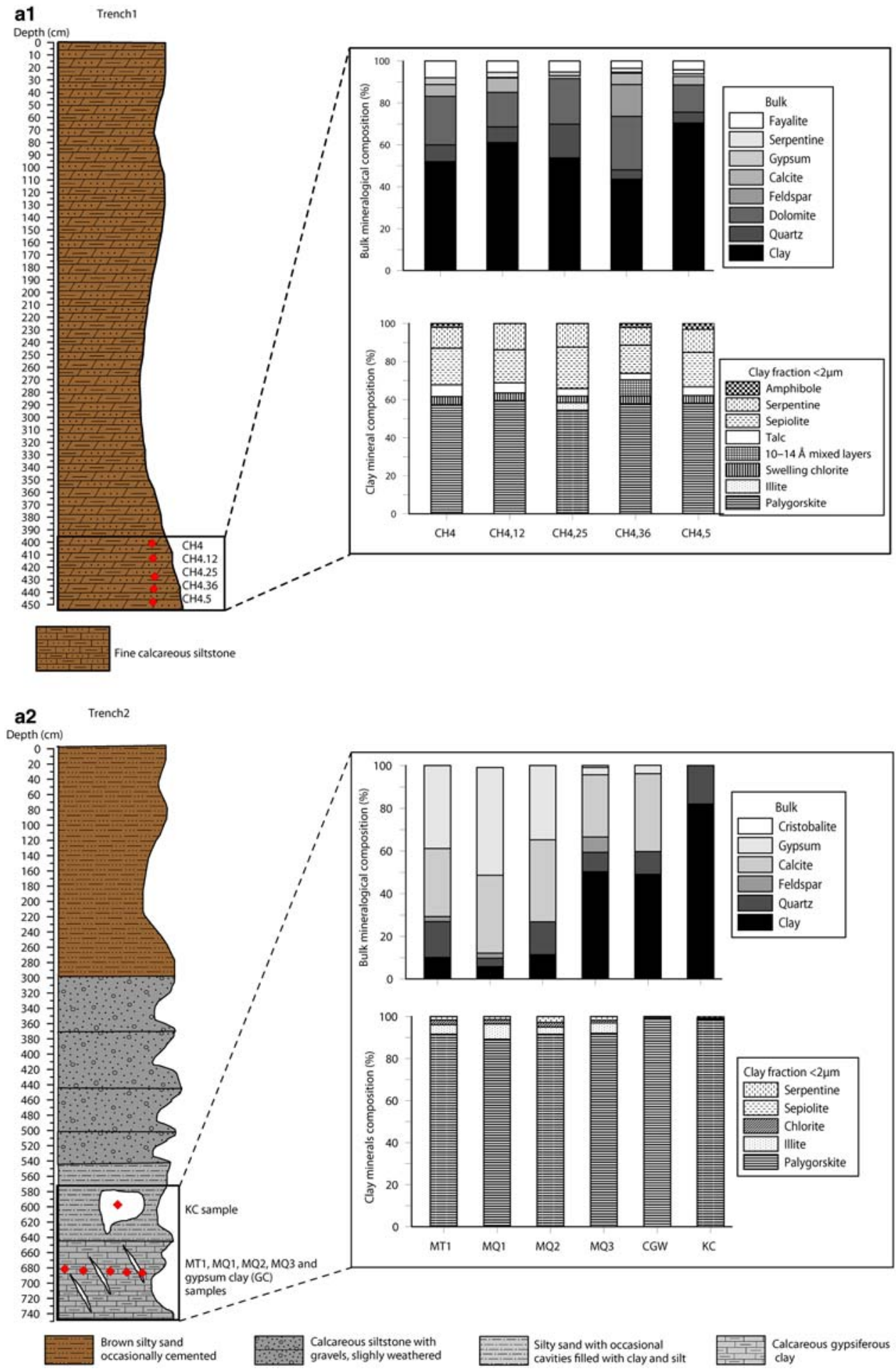

FIG. 2. (a) Sediment logs of Trench1, Trench2 and Drill and correlation of the lithostratigraphical units defined in the present study with units defined by Macklin et al. (2012) in the Dubai costal sequences. (b) Lithological description and mineralogical composition with depth: Trench1, Trench2 and Drill. 


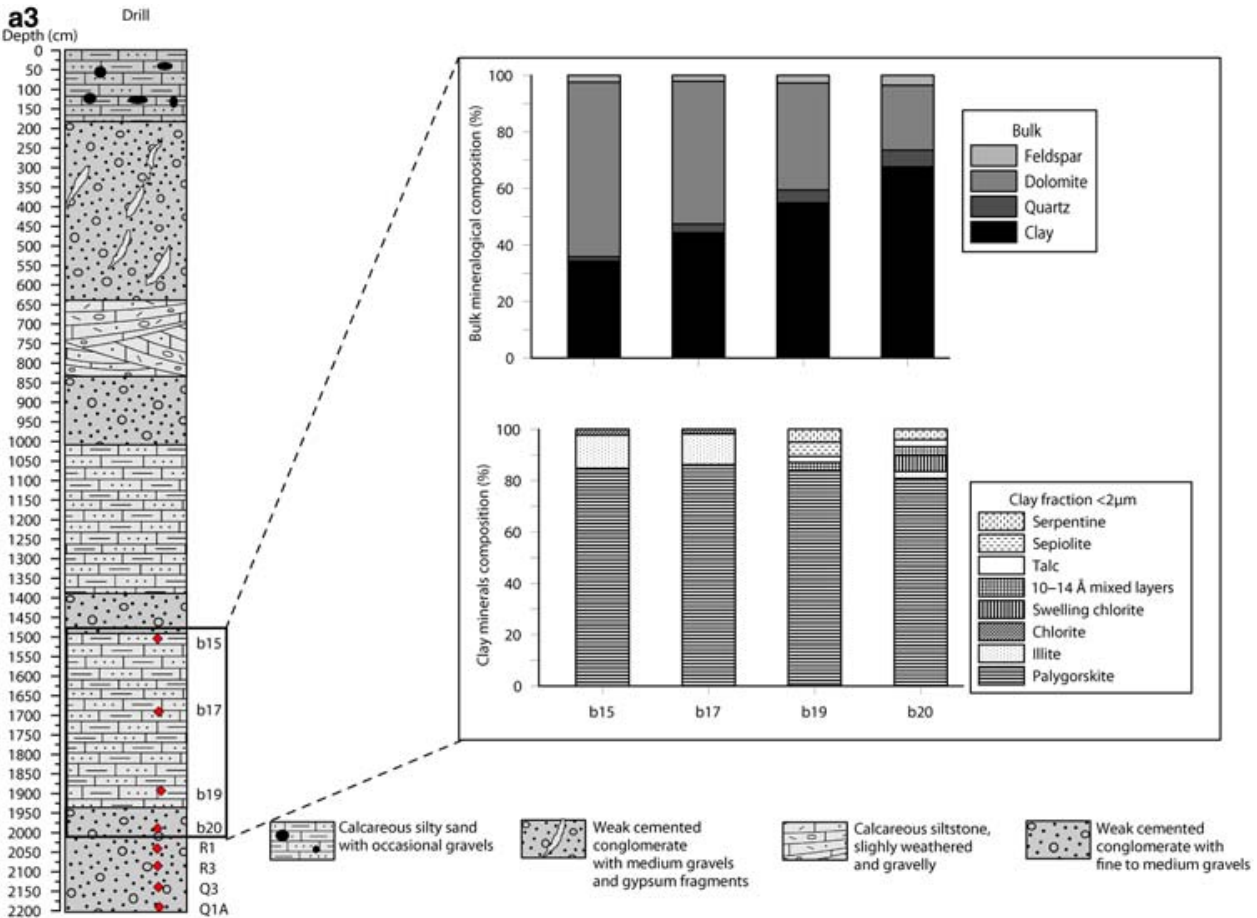

b

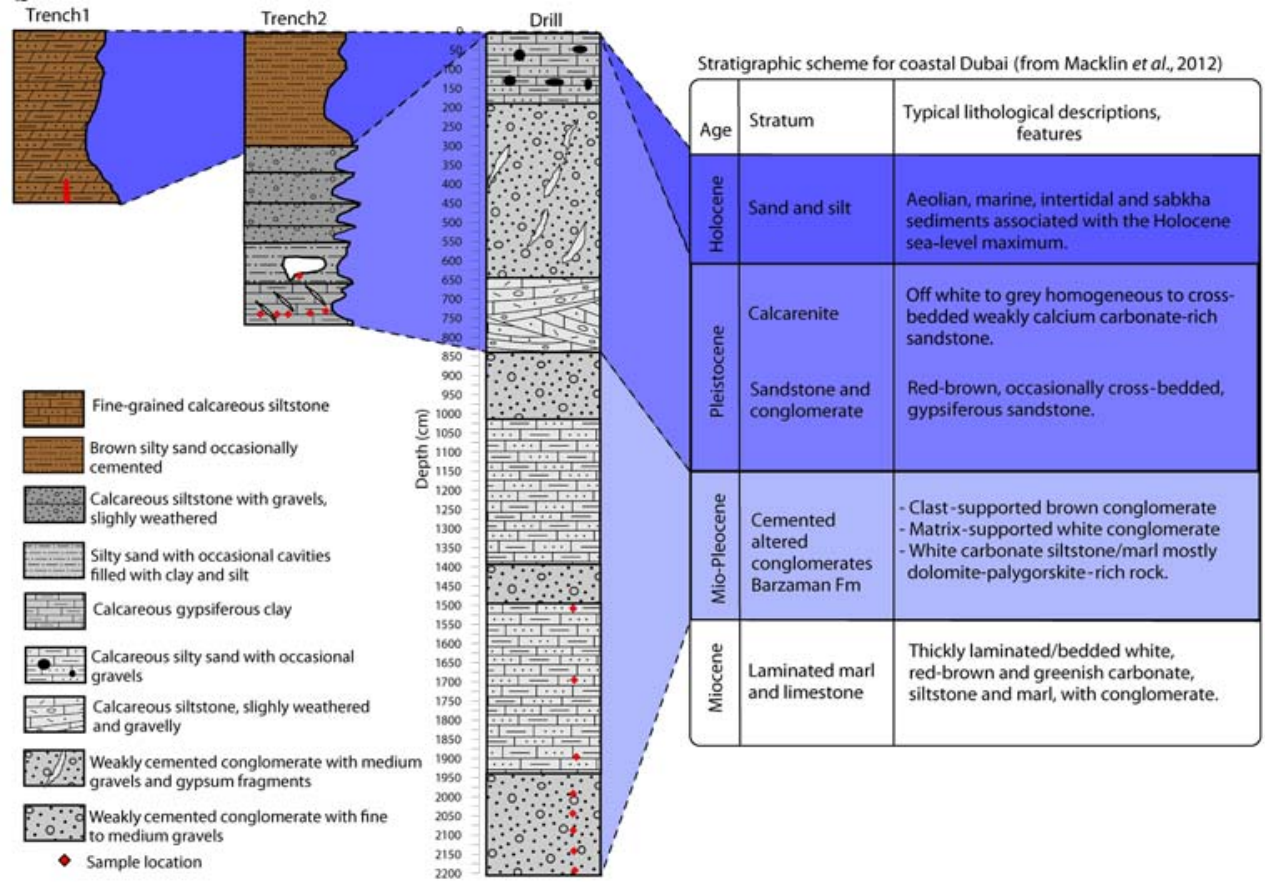

Fig. 2. Continued. 
TABLE 1. Spatial variation of bulk and clay-mineral composition (traces $\leq 3 \%$ ).

Bulk sediments

$\mathrm{Mg}-$

Samples Total clay Gypsum Quartz Calcite calcite Dolomite Feldspar Cristobalite Serpentine Fayalite

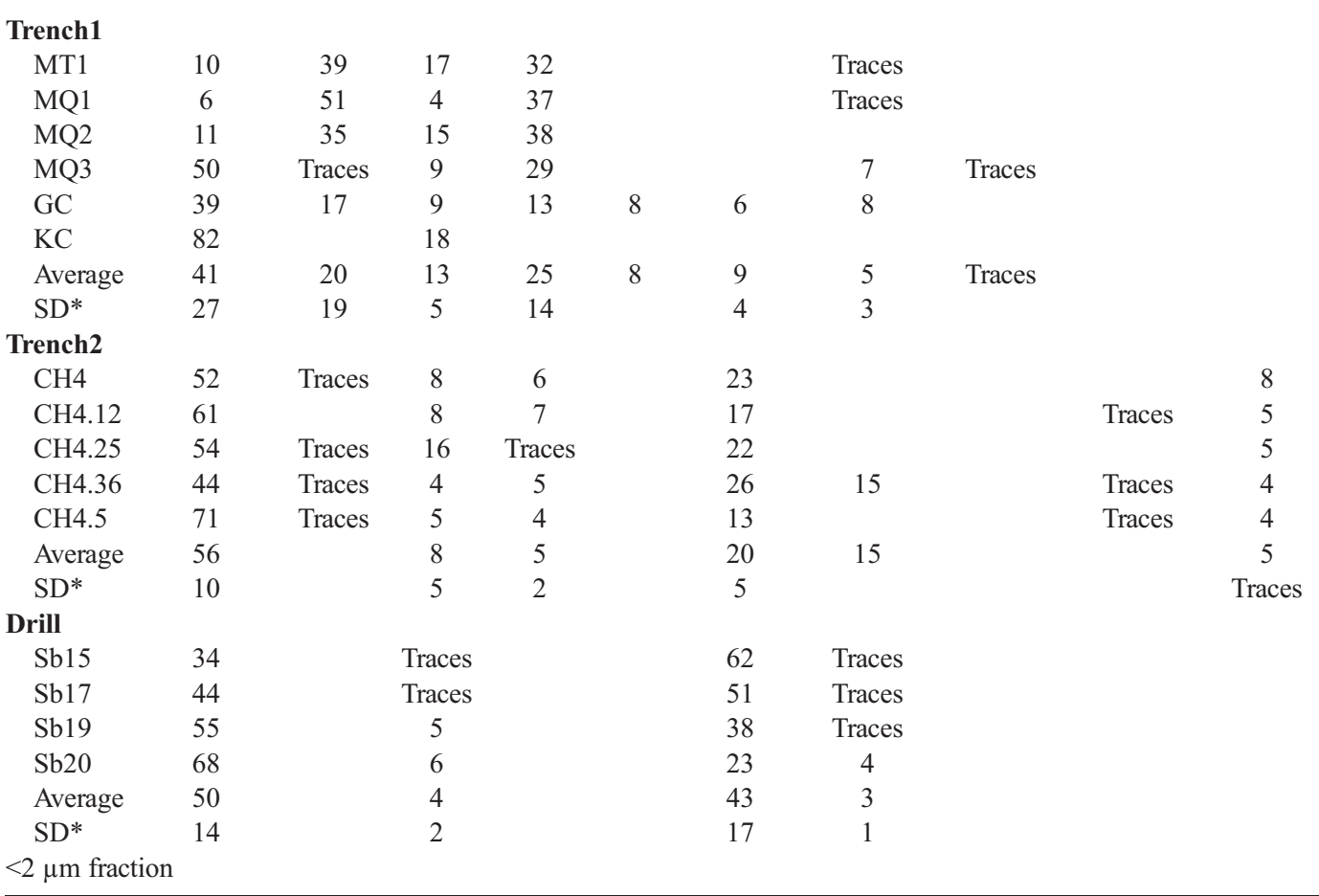

Swelling $\quad$ Mixed

Sample Palygorskite Sepiolite Chlorite chlorite Illite (10-14 Å) Serpentine Talc Amphibole Pyroxene

\begin{tabular}{|c|c|c|c|c|c|c|c|c|c|}
\hline \multicolumn{10}{|l|}{ Trench1 } \\
\hline MT1 & 92 & & Traces & & 5 & & Traces & & \\
\hline MQ1 & 89 & & Traces & & 7 & & Traces & & \\
\hline MQ2 & 92 & & Traces & & Traces & & Traces & & \\
\hline MQ3 & 92 & & Traces & & 5 & & Traces & & \\
\hline $\mathrm{GC}$ & 83 & 9 & Traces & & Traces & & Traces & & \\
\hline $\mathrm{KC}$ & 99 & Traces & Traces & & & & & & \\
\hline Average & 93 & 6 & & & 3 & & & & \\
\hline $\mathrm{SD}^{*}$ & 6 & 5 & & & 3 & & & & \\
\hline \multicolumn{10}{|l|}{ Trench2 } \\
\hline $\mathrm{CH} 4$ & 57 & 19 & & 4 & & & 11 & 6 & Traces \\
\hline CH4.12 & 60 & 17 & & 4 & & & 14 & 5 & \\
\hline CH4.25 & 54 & 22 & & 4 & 4 & & 12 & 4 & \\
\hline CH4.36 & 58 & 15 & & 4 & & 8 & 9 & Traces & Traces \\
\hline CH4.5 & 58 & 18 & & 4 & & & 12 & 5 & Traces \\
\hline
\end{tabular}


TABLE 1. (contd.)

\begin{tabular}{|c|c|c|c|c|c|c|c|c|c|c|}
\hline Sample & Palygorskite & Sepiolite & e Chlorite & $\begin{array}{l}\text { Swelling } \\
\text { chlorite }\end{array}$ & Illite & $\begin{array}{c}\text { Mixed } \\
\text { layers } \\
(10-14 \AA)\end{array}$ & Serpentine & Talc & Amphibole & Pyroxene \\
\hline Average & 57 & 18 & & 4 & 4 & 8 & 12 & 5 & & \\
\hline SD* & 2 & 3 & & 0 & & & 2 & 1 & & \\
\hline \multicolumn{11}{|l|}{ Drill } \\
\hline Sb15 & 85 & & Traces & & 13 & & & & & \\
\hline Sb17 & 86 & & Traces & & 12 & & & & & Traces \\
\hline Sb19 & 84 & 6 & & & & Traces & 5 & Traces & & Traces \\
\hline $\mathrm{Sb} 20$ & 81 & & & 6 & Traces & Traces & 4 & Traces & & Traces \\
\hline Average & & 84 & 6 & 2 & 6 & 9 & 3 & 5 & & 3 \\
\hline $\mathrm{SD}^{*}$ & & 2 & & 0.4 & & 6 & 0.3 & 1 & & 0 \\
\hline
\end{tabular}

SD* standard deviation.

serpentine, pyroxene, talc and olivine were in evidence. Halite was not quantified due to its low concentration.

In Trench1, the powdered bulk samples consist of clay minerals $(41 \pm 27 \%)$, calcite $(25 \pm 14 \%)$, gypsum (20 $\pm 19 \%)$, quartz $(13 \pm 5 \%)$, small amounts of dolomite $(9 \pm 4 \%)$ and feldspar $(5 \pm 3 \%)$. Mg-calcite was found only in the GC sample (8\%) (Table 1). The claymineralogical composition suggests that palygorskite is the predominant clay mineral component $(93 \pm 6 \%)$ with traces $(<5 \%)$ of chlorite, illite and serpentine. Sepiolite is only present in sample GC $(9 \%$, Table 1$)$.

In Trench2, the powdered bulk samples consist mainly of clay minerals $(56 \% \pm 10 \%)$, dolomite $(20 \% \pm 5 \%)$ and quartz $(8 \% \pm 5 \%)$. Calcite $(5 \% \pm 2 \%)$ and fayalite $(5 \% \pm 2 \%)$ are also present as minor phases. Feldspar appears only in CH4.36 sample (15\%) and gypsum and amphibole are present in traces. Regarding the clay fraction, palygorskite and sepiolite are the major clay phases with averages of $57 \pm 2 \%$ and $18 \pm 3 \%$ respectively, whereas serpentine $(12 \pm 2 \%)$, talc $(5 \pm 1 \%)$ and swelling chlorite $(4 \pm 0 \%)$ are minor phases. Illite (4\%) and 10-14 $\AA$ mixed layers (8\%) are only present in samples $\mathrm{CH} 4.25$ and $\mathrm{CH} 4.36$, respectively.

In the drill hole, clay minerals $(50 \pm 14 \%)$ and dolomite $(43 \pm 17 \%)$ are the most significant phases in the bulk sediments associated with traces of quartz $(4 \pm 2 \%)$ and feldspar $(3 \pm 1 \%)$. In the clay fraction, palygorskite $(84 \pm$ $2 \%)$ is the dominant phase. In addition, illite $(9 \pm 6 \%)$, serpentine $(5 \pm 1 \%)$, traces of chlorite $(2 \pm 0.4 \%), 10$ $14 \AA$ mixed layers and talc are present. Minor sepiolite occurs only in sample Sb19 (6\%).

The XRD analysis of oriented aggregates shows the predominance of palygorskite with minor sepiolite in places. The contribution of the palygorskite is highly variable (Figs 2,3). Minor clay minerals present consist largely of degraded chlorite, with some swelling interlayers and mixed-layers of swelling chlorite/chlorite.

\section{Environment of deposition (determined using petrographic microscopy)}

Petrographical analysis of two thin sections, taken from samples at a depth of $17 \mathrm{~m}$ in the drill hole, revealed the presence of wackestone, with dolomite and gypsum $(\sim 10 \%)$, characterized by poor sorting and some rounded lithoclasts of micritic limestone with pedogenetic structures, partially altered volcanic glass, silex grains (radiolarites), chlorite, silty quartz grains $(60 \mu \mathrm{m})$ and pyrite in a dolomitic micrite/microsparite matrix (Fig. 3a). These textures suggest the presence of calcareous/dolomitic palaeosols (calcretes/dolcretes). The same environment is observed down to a depth of $19 \mathrm{~m}$ with additional polycrystalline quartz grains. Further down, at a depth of $20 \mathrm{~m}$, a similar environment is present with additional elements such as dolomite and sandy quartz grains $(90 \mu \mathrm{m})$. At this deeper level, gypsum is more abundant ( 20\%, Fig. $3 b)$.

The hard crust, in its upper part at $21 \mathrm{~m}$ depth (R3 sample), contains calcareous/dolomitic palaeosols (calcretes/dolcretes) with pedogenetic structures, mollusc and foraminifer fragments, and gypsum $(\sim 10 \%)$ impregnations (Fig. 3c). Furthermore, two types of cement were identified; the first, which is marine vadose cement, forms a microstalactitic rim $(150 \mu \mathrm{m})$ with alternating micritic and bladed spar while the second is drusy to equigranular $(200 \mu \mathrm{m})$ sparite indicating phreatic meteoric origin (Fig. 3d). The depositional environment is considered to have been beach-rock facies (upper part of intertidal zone). However, further down and from 21 to $22 \mathrm{~m}$ depth (Q3 

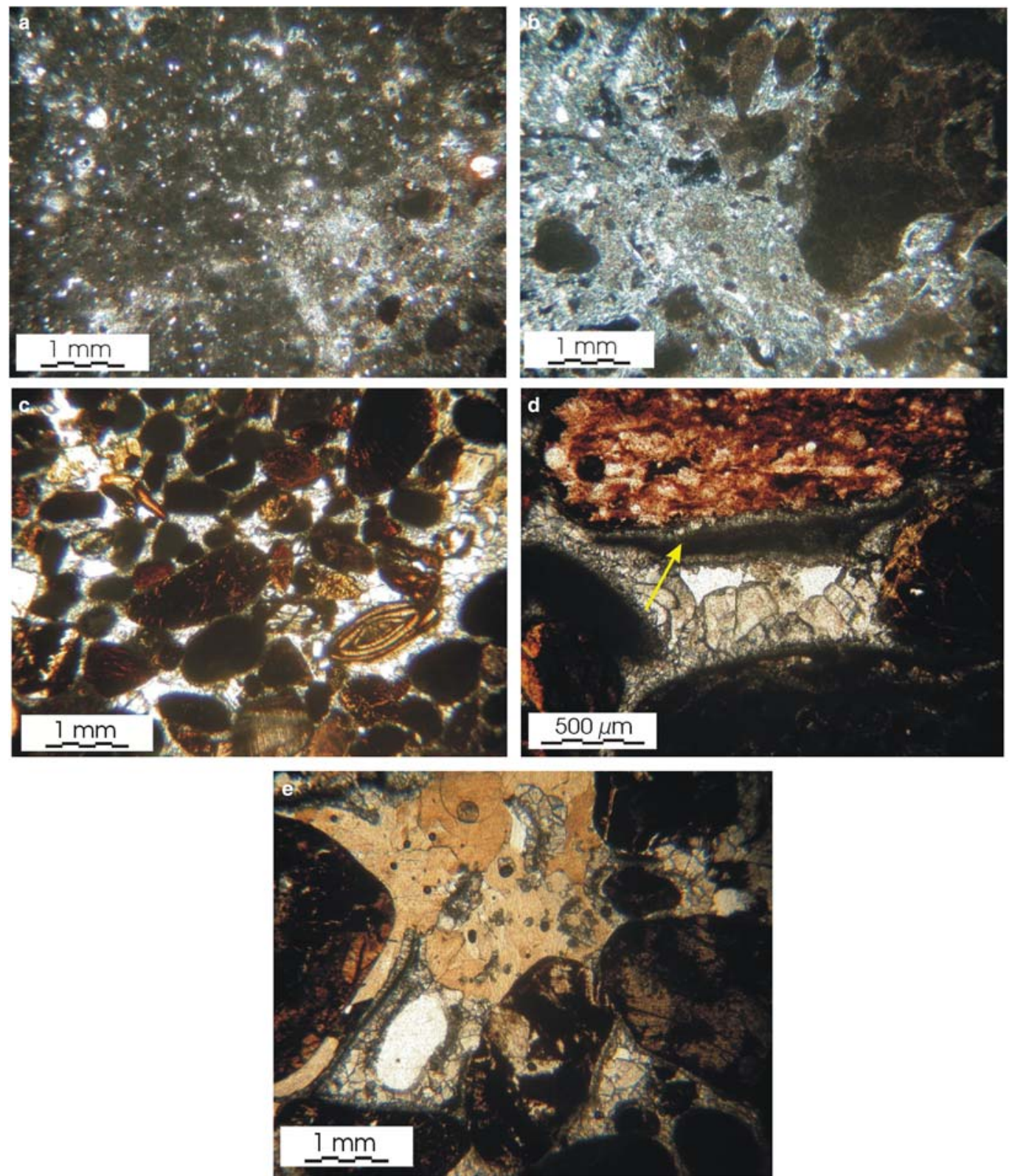

FIG. 3. Micrographs of thin sections (plane polarized light) of the Drill samples: (a) pedogenic structures and micritic clasts (sample Sb17); (b) micritic clast with pedogenetic structures and gypsum (sample Sb20); (c) packstone with volcanic-glass fragments, calcareous lithoclasts with pedogenetic structures (sample R3); (d) microstalactitic rim indicated by arrow, developed in the upper intertidal zone, followed by continental drusy spar (sample R3); and (e) pinkish crystals are secondary gypsum partially replacing spar cement (sample Q3).

and Q1A samples), the facies is sandy or conglomeratic limestone with dominant rounded volcanic glass fragments and clasts of pedogenetic limestone (Fig. 3e). The depositional environment corresponds to a wave-exposed beach (from upper intertidal to subtidal zones) and lithification (cementation) started in a marine phreatic or vadose zone and ended in a phreatic meteoric continental zone. 

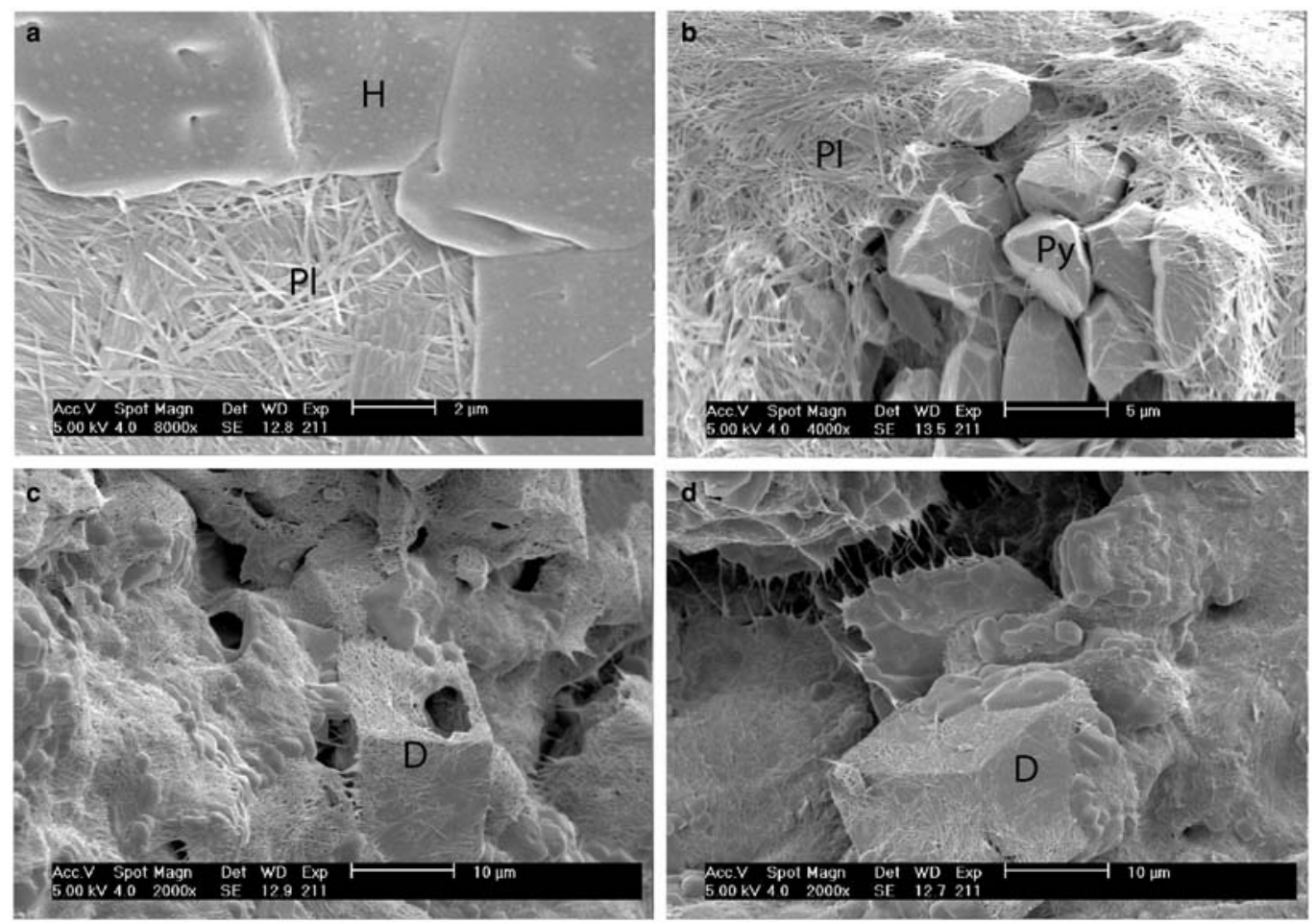

FIG. 4. SEM images of sample Ch4.36 from Trench1: (a) flat surface formed by palygorskite (Pl) mats partially covered by partially dissolved platelets of halite $(\mathrm{H})$; (b) overview of palygorskite $(\mathrm{Pl})$ mats covering a multifaceted detrital pyroxene (Py) from the ultramafic basement; (c) irregular surface, showing palygorskite fibres covering crystals of almost dissolved dolomite (D); (d) detachment of palygorskite fibre.

\section{Microtexture}

The SEM images of calcareous siltstone from Trench1 (sample Ch4.36) showed palygorskite mats partially covered by platelets of partially dissolved halite (Fig. 4a). Palygorskite mats wrapped around a mass of multifaceted crystals of pyroxene, a mineral inherited from the ultramafic substrate (Fig. 4b). Also, the palygorskite fibres cover crystals of almost completely dissolved dolomite (Fig. 4c). The dissolution of dolomite was suggested by the palygorskite fibres strapping and coating the crystals and fitting to the dolomite form. Furthermore, when the crystal dissolved, the fibres retained their shape for a brief period before falling and piling (Fig. 4c).

Examination of the GC sample from Trench2 by SEM revealed the occurrence of palygorskite in the calcareous gypsiferous clay sediments at a depth of $\sim 6.90 \mathrm{~m}$, as was confirmed by the typical fibrous morphology (Fig. 5c). The palygorskite mats were formed by successive interwoven and perpendicular layers of elongated and bonded fibres, up to $5 \mu \mathrm{m}$ long and $55-115 \mathrm{~nm}$ wide. The palygorskite fibres grow under and between the rhombohedral dolomite crystals, coat them and finally cover them completely. Dissolution is indicated by sub-rounded voids which correspond to former dolomite crystals. Sepiolite occupies the voids left by dissolved crystals; it is then deformed and stacked, hence the folded and draped aspect (Fig. 5a). Neoformation of gypsum occurred after the formation of palygorskite as indicated by agglomeration of partially dissolved irregular gypsum crystals enveloping bundles of palygorskite fibres (Fig. 5b). In addition, moderately scarce altered talc crystals, formed in the calcareous gypsiferous clay sediments with some altered chlorite were also observed (Fig. 5c). The KC sample exhibited only boquets or balls of elongated and curved thin palygorskite fibres. Dolomite and calcite are absent, but traces of talc are present.

Calcareous silty sand facies, present in the drill hole at depths of between 15 and $19.50 \mathrm{~m}$, contain abundant 

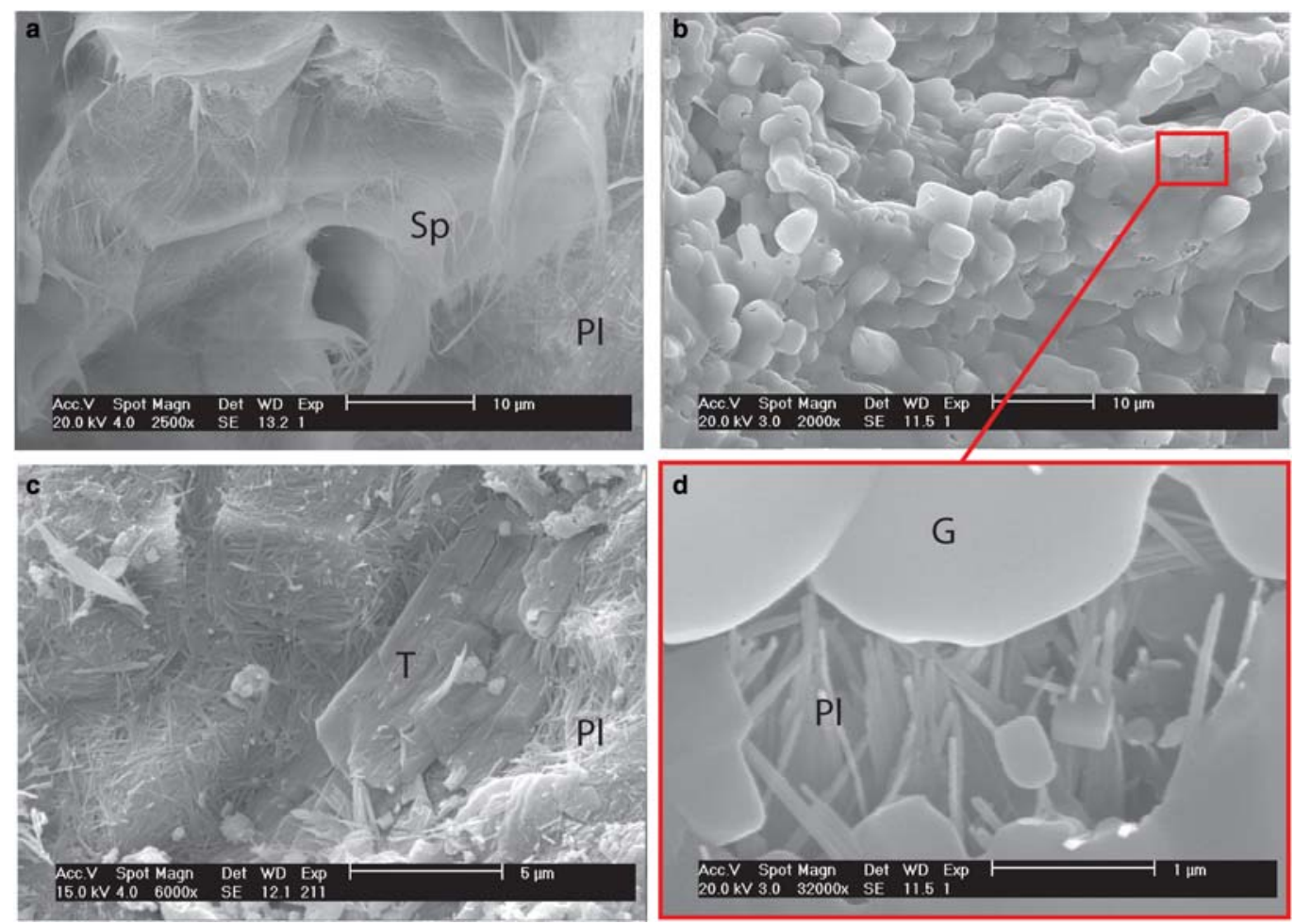

FIG. 5. SEM images of the calcareous gypsiferous clay (CG) sample from Trench2: (a) draped and folded voile of sepiolite $(\mathrm{Sp})$ covering mats of palygorskite $(\mathrm{Pl})$. The sub-rounded voids correspond to dissolved crystals; (b) agglomeration of irregular gypsum crystals partially dissolved enveloping bundles of palygorskite fibres, suggesting later precipitation of the gypsum compared to sepiolite and palygorskite (enlargement shown in part d); (c) moderately altered talc (T) crystal.

palygorskite fibres (Figs 6 and 7). In its upper part, sample Sb17 shows mats or felting of palygorskite covering, partially or completely, scattered euhedralsubhedral crystals of dolomite or calcite (Fig. 6a). Dissolution is indicated by the fresh imprint left by recently dissolved dolomite crystals, formerly embedded or pasted on palygorskite mats (Fig. 6b). Palygorskite is present in association with anhedral dolomite crystals bounded by thin fibres, as well as with strongly altered chlorite crystals. Weathering is indicated by the presence of dolomite crystals slightly altered and detached from the palygorskite mats (Fig. 7b).

Evaporitic conditions are indicated by the presence of elongated fibres of palygorskite stacked and pasted on gypsum (sample Sb19), suggesting its later precipitation (Fig. 7a). As indicated previously, in the upper part of the calcareous, silty sand facies, the complete dissolution of former cubic or rhombohedral crystals of dolomite was also shown by the imprints left when the fibres covering the crystal facets fell, broke and dispersed (Fig. 7b). In addition, strongly altered crystals of talc associated with the palygorskite mats are also present.

Samples R1 and R3 contain very fine needles or relatively short fibres of serpentine, sometimes curved, associated locally with altered grains of olivine. The olivine grains are altered extensively to serpentine; the fibres thereof are clearly visible on the edge of a cavity surrounded by palygorskite mats, gypsum and halite. Some olivine grains are altered extensively to goethite (Fig. 8b). Weathered olivine shows cells and microchannels $(\varnothing=3-4 \mu \mathrm{m})$ associated with platelets of completely altered chlorite (Fig. 8c,d).

\section{DISCUSSION}

The Barzaman Formation conglomerates were deposited near the shore under a fluvial regime during the MiocenePliocene (Béchennec et al., 1990, 1993; Farrant et al., 2012) when rainfall and erosion were high (Azam, 2007; Macklin et al., 2012; Lacinska et al., 2014). 

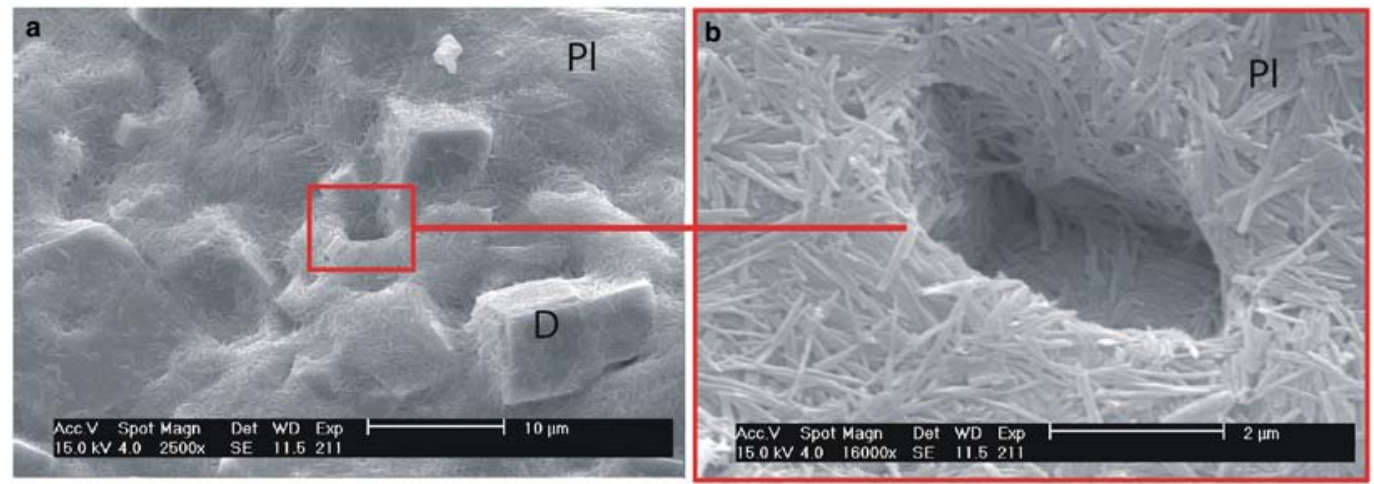

FIG. 6. SEM images of the calcareous silty sand sample (Sb17): (a) felting of palygorskite ( $\mathrm{Pl}$ ) covering scattered crystals of dolomite (D); (b) fresh imprint left by a recently dissolved crystal, probably halite, previously pasted on palygorskite (Pl) mats.

\section{Conglomerate facies $(20-22 \mathrm{~m})$}

The conglomerate is composed mainly of quartz, clasts of pedogenetic limestone, volcanic glass fragments and weathered fragments of ultramafic rock from erosion of the ophiolite belt. The matrix is calcareous with quartz and dolomite. Diagenesis and alteration of the ophiolite-rich conglomerates are heavily dependent on the availability of groundwater and specific $\mathrm{pH}$ conditions (Stanger, 2005). The change from humid climate and high rainfall during the Late Miocene-Pliocene to progressively increasing aridity during the Pleistocene period affected the Barzaman Formation (Rodgers \& Gunatilaka, 2003). Intensified rainfall affects the degree of fluvial activity and might have triggered erosion in the watershed and subsequently enhanced the production of the ophiolite-derived detritus. Periods with more precipitation might also have changed the groundwater balance available for cementation and pedogenesis (recrystallization). Cementation began by precipitation of carbonate in the unsaturated (vadose) zone in the wave-exposed beach environment, probably with periodic ponding and evaporation of vadose waters (Harrison, 1977) (Fig. 9).

Post-depositional erosion started in marine phreatic or vadose zones and ended in the phreatic meteoric continental zone (Fig. 3). Serpentinization proceeded partially in situ and partly as a post-depositional process through weathering and transformation of olivine as attested by the fresh fibres of serpentine on the entities derived from the pedogenetic process (Fig. 8a,b). The occurrence of gypsum and halite
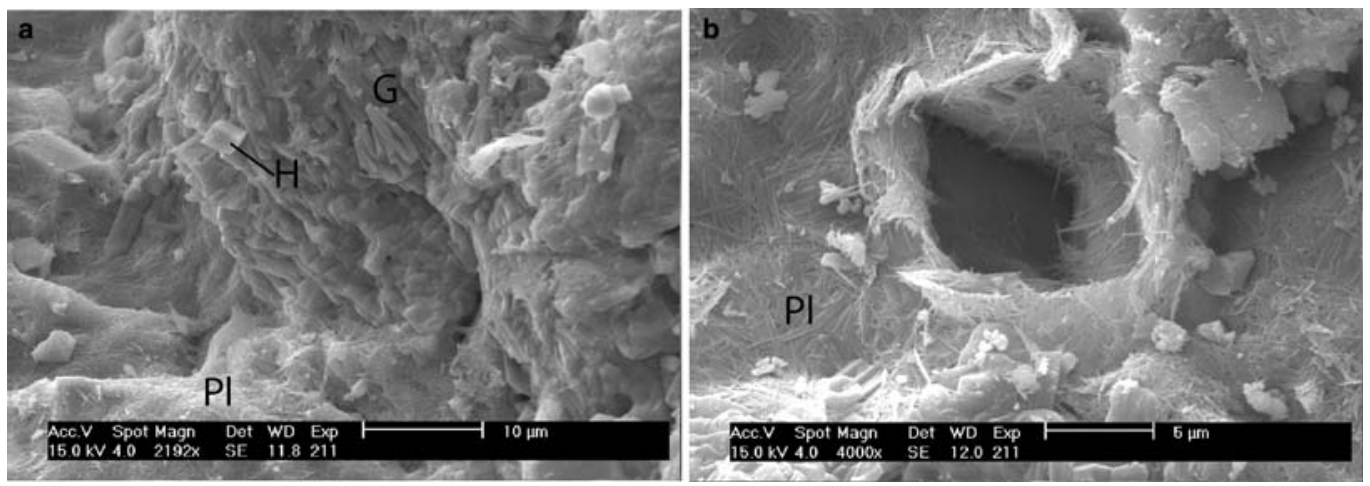

FIG. 7. SEM images of the calcareous silty sand sample (Sb19) from the Drill: (a) gypsum (G) covering palygorskite (P1) mats indicating later precipitation; (b) imprint of former dolomite or calcite crystal. The fibres coated the crystals fitting to its form and, once the crystals were dissolved, the fibres collapsed. 

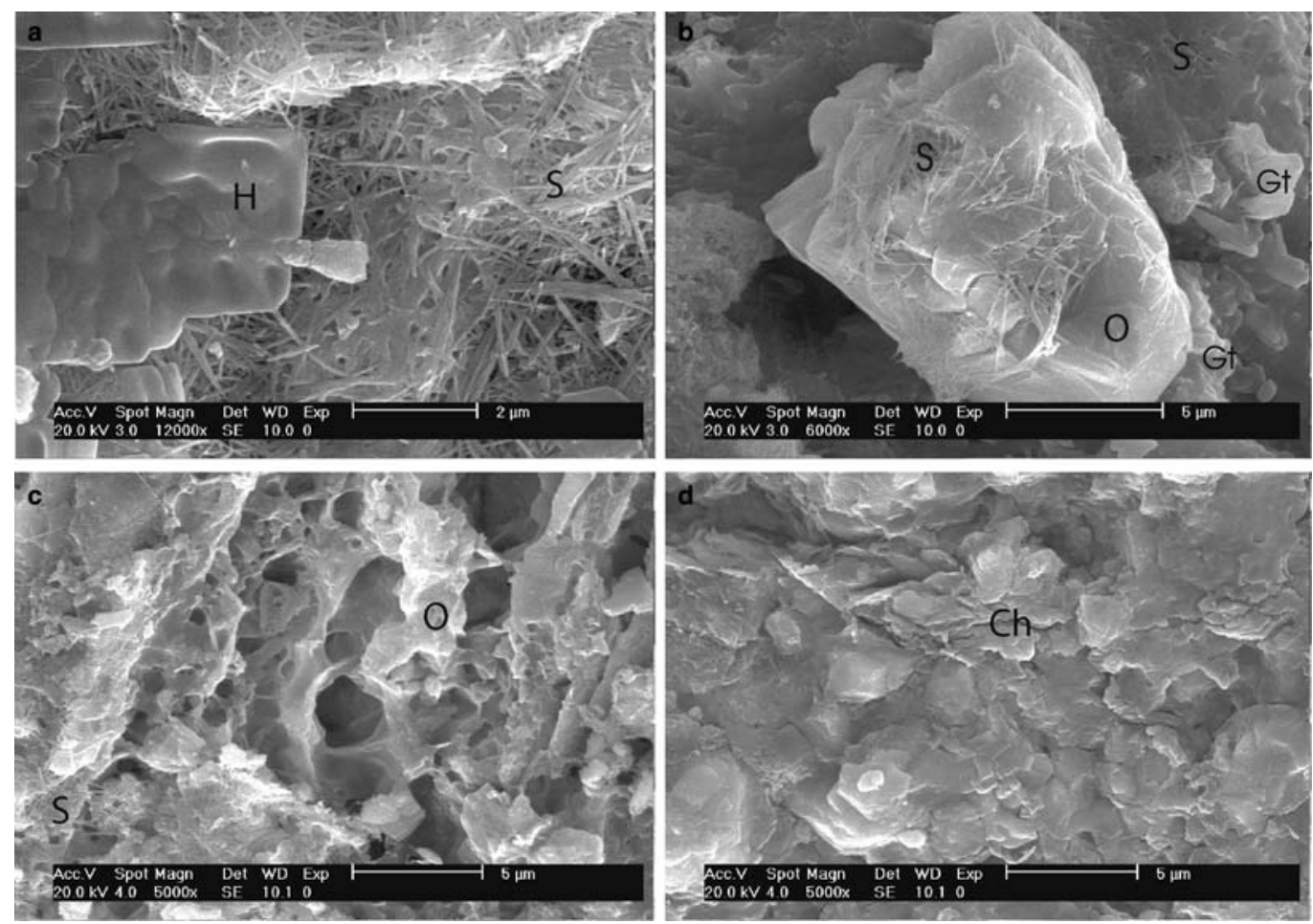

FIG. 8. SEM images of the hard crust from the Drill samples: (a) R1 sample: mats of small relatively altered fibres of serpentine covered by halite $(\mathrm{H})$; (b) olivine grain $(\mathrm{O})$ altered to serpentine $(\mathrm{S})$; the fibres are clearly visible on the edge of cavity; (c) R3 sample: olivine crystal (O) strongly altered with cavities, cells and micro-channels $(\varnothing=3-4 \mu \mathrm{m})$; (d) platelets of altered chlorite $(\mathrm{Ch})$.

suggests an evaporitic environment. The alkaline $\mathrm{pH}$ due to saline marine water led to hydrolysis of inherited minerals, especially phyllosilicates (chlorite), ultramafic minerals (olivine), feldspars and carbonates (dolomite and calcite). Arid climatic conditions increased the $\mathrm{pH}$ and salinity of the solution which, in turn, favoured precipitation of authigenic dolomite particularly the Mg-rich variety. Ophiolite rocks make up the primary source of $\mathrm{Mg}$ and $\mathrm{Si}$ ions, whereas $\mathrm{Ca}$ was mainly provided by the calcareous sandstone in the vicinity of the explored area, and/or either by groundwater or calcareous silty sand layers (Fig. 1). Additional $\mathrm{Si}$ and $\mathrm{Al}$ were provided by the surrounding siliciclastic rocks and phyllosilicates such as illite and chlorite which underwent chemical weathering and hydrolysis (Fig. 9). The absence of palygorskite at this deeper level of the conglomerate could be interpreted by the lack of Si, Mg and Al. In contrast, the occurrence of calcite and dolomite was possible. In such conditions, goethite was neoformed by Fe released during serpentinization (Chardot et al., 2007).

\section{Calcareous silty sand facies $(15-19 \mathrm{~m})$}

Two mineral groups were distinguished. The first includes inherited minerals from the previously altered substrate transported mostly by the river and to a lesser degree by the wind and found together in their final terrace deposit. The detrital minerals are quartz, feldspars, amphibole, pyroxene, serpentine, olivine, illite, chlorite (degraded) and talc. These detrital assemblies refer to parental ultramafic rocks (ophiolite). The second comprises neoformed or penecontemporary minerals formed by precipitation and crystallization: dolomite, calcite, palygorskite, sepiolite and halite (Singer, 1979; Zaaboub et al., 2005). The simultaneous presence of calcite, gypsum and palygorskite indicates sedimentation in an evaporitic environment, with the presence of quartz and feldspars. Halite is also present but was not quantified because it is a secondary mineral, probably resulting from between-pores precipitation, following the evaporation of sea water flowing in cohesive or 


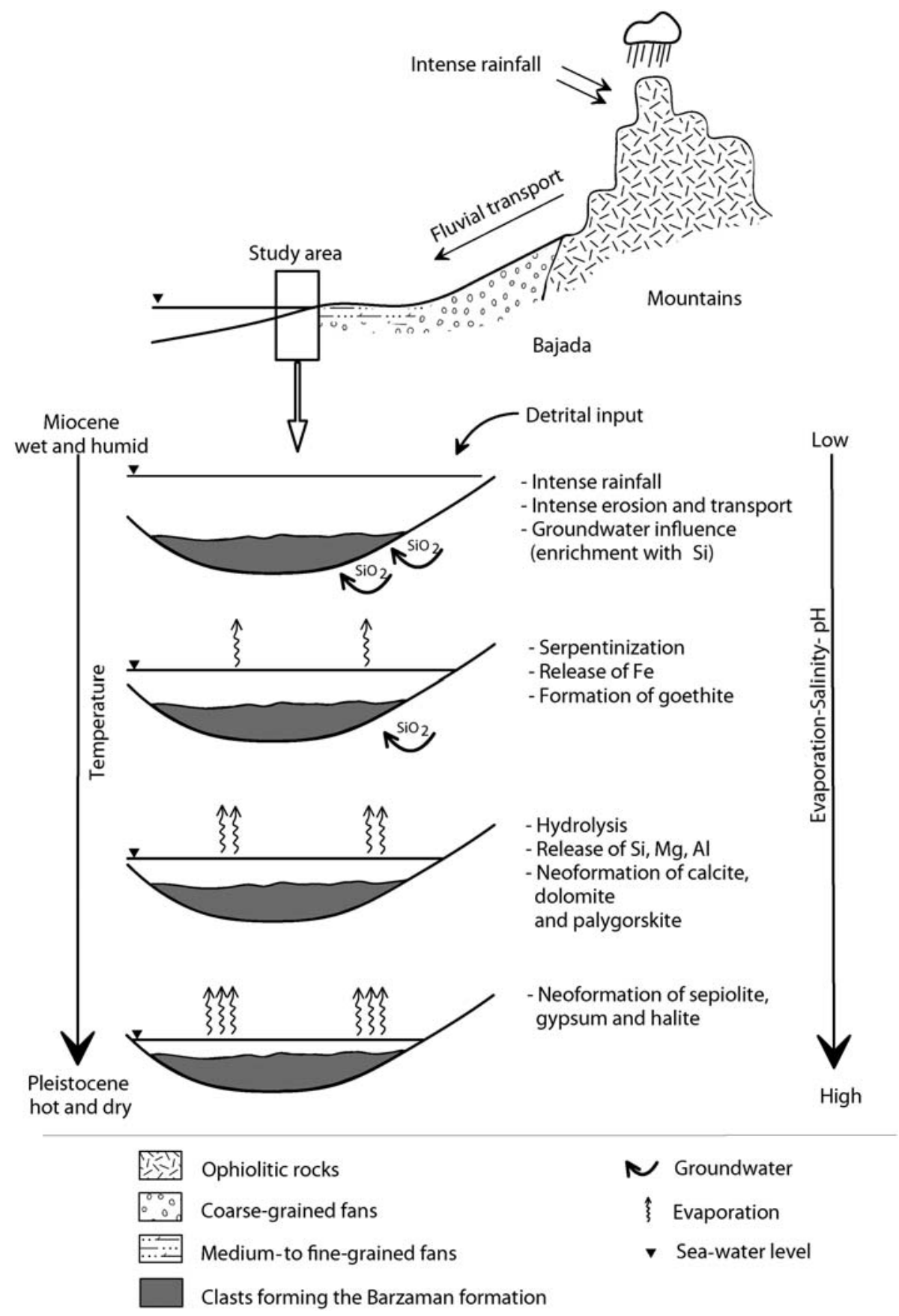

Fig. 9. Schematic representation of diagenetic evolution in the Barzaman Formation.

non-cohesive sediments. Palygorskite occurs in the form of bouquets or mats, which coat crystals of calcite and/or dolomite. Neoformation of dolomite and calcite is demonstrated by the fact that the palygorskite fibres are stacked on the surface and included within and near the surface of the carbonate crystals. 


\section{Calcareous gypsiferous clay facies $(\sim 7 \mathrm{~m})$}

The mineralogical assemblage of the calcareous gypsiferous clay consists mainly of calcite, palygorskite and gypsum. The quartz and K-feldspar contents vary but are also major phases, while dolomite is absent. The origin of the calcareous gypsiferous clay would thus be evaporation of sea water in a sabkha environment, possibly combined with wind-blown deposition of clay and silt particles (Purser, 1985). The carbonate content is probably partly organic, of algal origin (Gebelein \& Hoffman, 1973). These conditions favour precipitation and crystallization of calcite, palygorskite, gypsum and halite in lagoonal or/and sabkha contexts. Palygorskite fibres associated with crystals of gypsum are observed. Gypsum is the last precipitated mineral, which suggests that it is neoformed by precipitation in a saline environment such as a sabkha (Fig. 5b). By contrast, chlorite is a detrital phyllosilicate from the eroded areas and is altered (Fig. 5c). Talc is also an inherited mineral from the ultramafic rocks and is moderately to strongly altered. Post-depositional conditions are attested by the presence of palygorskite and sepiolite (Fig. 5a). The presence of sub-rounded voids corresponds to the dissolution of some former crystals. Gypsum precipitated later than palygorskite because it is covering the bundles of palygorskite fibres.

Evaporitic conditions in a karstic environment occurred directly above the calcareous gypsiferous clay (Gutiérrez et al., 2008) (Fig. 2b). The karst could be the reason for dissolution of the gypsum and halite already formed by upwelling of groundwater (Butler, 1965) which is capable of dissolving the gypsum in hot seasons. Evaporitic conditions are also highlighted by the presence of palygorskite.

\section{Calcareous siltstone facies $(4-4.5 \mathrm{~m})$}

More relicts from the detrital minerals are present in this facies. Among them, serpentine might have been derived from the basaltic rocks or from in situ transformation of ultramafic rocks. Palygorskite is present as a neoformed mineral (Fig. 4b). Feldspar, pyroxene and quartz are detrital and probably derived from the erosion of the clastic rocks belonging to Jebal Ali (Fig. 1). The presence of a wide range of inherited minerals in this calcarenite deposit suggest cemented aeolian deposits (former dunes) (Brooke et al., 2003). Dissolution affected dolomite which is at least partially neoformed. The palygorskite crystallized before or simultaneously with the dissolution of dolomite (Fig. 4c). Brown calcareous silty clay was deposited under vadose and oxidizing environmental conditions (McBride, 1974; Lovley et al., 1990). Significant amounts of dolomite and palygorskite are formed by direct co-precipitation from $\mathrm{Ca}, \mathrm{Mg}, \mathrm{Al}, \mathrm{Fe}$ and $\mathrm{Si}$ ionsrich solutions. The presence of gypsum and halite indicates evaporitic conditions related to the development of a sabkha environment (Lovley et al., 1990) (Fig. 9).

\section{CONCLUSIONS}

The Barzaman Formation consists of a series of fluvialsediment sequences found between the margin of the ophiolitic Hajar Mountains (Oman-UAE Ophiolite belt) and the sea (Arabian Gulf). It consists of a sequence of rocks dominated by variably cemented Miocene-Pliocene conglomerates, which are composed largely of ultramafic rocks and other clasts. The present study has revealed the occurrence and genesis of palygorskite and sepiolite in relation to the change of environmental conditions, including evaporitic and sabkha environments.

The Miocene-Pliocene conglomerates which constitute the hard crust of the Barzaman Formation have undergone pedogenesis. Post-depositional erosion started in marine phreatic or vadose zones highlighted by the neoformation of calcite and dolomite as well as of serpentine from weathering of olivine. Goethite is neoformed from $\mathrm{Fe}$ which resulted from serpentinization; chlorite and illite are detrital. The absence of palygorskite at this level is interpreted by the lack of $\mathrm{Mg}$ and $\mathrm{Si}$ ions.

The calcareous, silty clay facies is formed by inherited minerals including quartz, feldspars, pyroxene, serpentine, olivine, illite, chlorite and talc. Post-depositional conditions were indicated by the neoformation of dolomite, palygorskite, sepiolite and halite under evaporitic conditions. Similar evaporitic conditions occurred in the calcareous gypsiferous clay facies attested by neoformation of palygorskite, sepiolite, gypsum and halite. A karstic environment was also developed on this facies.

The calcareous siltstone facies is affected by relatively hot, vadose and oxidizing environmental conditions leading to the genesis of dolomite and palygorskite by direct precipitation from $\mathrm{Ca}, \mathrm{Mg}, \mathrm{Al}, \mathrm{Fe}$ and Si-rich solutions. Gypsum and halite indicated evaporitic conditions related to the development of sabkha environments.

\section{REFERENCES}

Alsharhan A.S., Strohmenger C.J. \& Al-Mansoori A. (2014) Mesozoic Petroleum Systems of Abu Dhabi, United Arab Emirates. Pp. 679-711 in: Petroleum 
Systems of the Tethyan Region (L. Marlow, C.E. Kendall, and L.A. Yose, editors). American Association of Petroleum Geologists, Memoir 106.

Azam S. (2007) Study on the geological and engineering aspects of anhydrite/gypsum transition in the Arabian Gulf coastal deposits. Bulletin of Engineering Geology and the Environment, 66, 177-185.

Badraoui M., Bloom P.R. \& Bouabid R. (1992) Palygorskite-smectite association in a xerochrept of the high Chaouia region of Morocco. Soil Science Society of America Journal, 56, 1640-1646.

Béchennec F., Le Métour J., Rabu D., Bourdillon-deGrissac C., De Wever P., Beurrier M.t. \& Villey M. (1990) The Hawasina nappes: Stratigraphy, palaeogeography and structural evolution of a fragment of the south-Tethyan passive continental margin. Pp. 213-223 in: The Geology and Tectonics of the Oman Region (A.H.F. Robertson, M.P. Searle and A.C. Ries, editors). Special Publications, 49, Geological Society, London.

Béchennec F., Le Métour J., Platel J. \& Roger J. (1993) Explanatory notes to the geological map of the sultanate of Oman, scale 1/1,000,000. Directorate General of Minerals, Ministry of Petroleum and Minerals, Oman.

Birsoy R. (2002) Formation of sepiolite-palygorskite and related minerals from solution. Clays and Clay Minerals, 50, 736-745.

Biscaye P.E. (1965) Mineralogy and sedimentation of recent deep-sea clay in the Atlantic ocean and adjacent seas and oceans. Geological Society of America Bulletin, 76, 803-832.

Boote D., Mou D. \& Waite R. (1990) Structural evolution of the Suneinah foreland, central Oman mountains. Pp. 397-418 in: The Geology and Tectonics of the Oman Region (A.H.F. Robertson, M.P. Searle and A.C. Ries, editors). Special Publications, 49, Geological Society, London.

Brooke B.P., Murray-Wallace C.V., Woodroffe C.D. \& Heijnis H. (2003) Quaternary aminostratigraphy of eolianite on Lord Howe island, southwest Pacific Ocean. Quaternary Science Reviews, 22, 387-406.

Butler G. (1965) Early Diagenesis in the Recent Sediments of the Trucial Coast of the Persian Gulf. $\mathrm{PhD}$ thesis, University of London.

Callen R.A. (1984) Clays of the palygorskite-sepiolite group: Depositional environment, age and distribution. Pp. 1-37 in: Palygorskite-Sepiolite (E. Singer and E. Galán, editors) Developments in Sedimentology, 37, Elsevier, Amsterdam.

Chamley H. (1989) Clay Sedimentology. Springer-Verlag, Berlin, 623 pp.

Chardot V., Echevarria G., Gury M., Massoura S. \& Morel J. (2007) Nickel bioavailability in an ultramafic toposequence in the Vosges Mountains (France). Plant and Soil, 293, 7-21.
Cook H.E., Johnson P.D., Matti J.C. \& Zemmels I. (1975) $I V$. Methods of sample preparation, and X-ray diffraction data analysis, X-ray mineralogy laboratory, Deep Sea Drilling Project, University of California, Riverside. Initial Reports of the Deep Sea Drilling Project, 25.

Daoudi L. (2004) Palygorskite in the uppermost CretaceousEocene rocks from Marrakech High Atlas, Morocco. Journal of African Earth Sciences, 39, 353-358.

Farrant A., Price S., Arkley S., Finlayson A., Thomas R. \& Leslie A. (2012) Geology of the Al Lisaili 1: 100,000 map Sheet, 100-6, United Arab Emirates. British Geological Survey, Keyworth, Nottingham, UK.

Gebelein C.D. \& Hoffman P. (1973) Algal origin of dolomite laminations in stromatolitic limestone. Journal of Sedimentary Research, 43, 603-613

Golden D., Dixon J., Shadfan H. \& Kippenberger L. (1985) Palygorskite and sepiolite alteration to smectite under alkaline conditions. Clays and Clay Minerals, 33, 44-50.

Gutiérrez F., Calaforra J., Cardona F., Ortí F., Durán J. \& Garay P. (2008) Geological and environmental implications of the evaporite karst in Spain. Environmental Geology, 53, 951-965.

Harrison R. (1977) Caliche profiles: Indicators of nearsurface subaerial diagenesis, Barbados, West Indies. Bulletin of Canadian Petroleum Geology, 25, 123-173.

Hillier S. \& Pharande A. (2008) Contemporary pedogenic formation of palygorskite in irrigation-induced, salinesodic, shrink-swell soils of Maharashtra, India. Clays and Clay Minerals, 56, 531-548.

Hong H., Yu N., Xiao P., Zhu Y., Zhang K. \& Xiang S. (2007) Authigenic palygorskite in Miocene sediments in Linxia basin, Gansu, Northwestern China. Clay Minerals, 42, 45-58.

Isphording W.C. (1973) Discussion of the occurrence and origin of sedimentary palygorskite-sepiolite deposits. Clays and Clay Minerals, 21, 391-401.

Kiessling W., Flügel E. \& Golonka J. (2003) Patterns of Phanerozoic carbonate platform sedimentation. Lethaia, 36, 195-225.

Knidiri A., Daoudi L., El Ouahabi M., Rhouta B., Rocha F. \& Fagel N. (2014) Palaeogeographic controls on palygorskite occurrence in Maastrichtian-Palaeogene sediments of the western High Atlas and Meseta Basins (Morocco). Clay Minerals, 49, 595-608.

Lacinska A.M., Styles M.T. \& Farrant A.R. (2014) Nearsurface diagenesis of ophiolite-derived conglomerates of the Barzaman Formation, United Arab Emirates: A natural analogue for permanent $\mathrm{CO}_{2}$ sequestration via mineral carbonation of ultramafic rocks. Pp. 343-360 in: Tectonic Evolution of the Oman Mountains (H.R. Rollinson, M.P. Searle, I.A. Abbasi, A.I. Al-Lazki \& M.H. Al Kindi, editors). Special Publications, 392, Geological Society, London.

Lokier S.W. (2013) Coastal sabkha preservation in the Arabian Gulf. Geoheritage, 5, 11-22. 
Lovley D.R., Chapelle F.H. \& Phillips E.J. (1990) Fe (III)reducing bacteria in deeply buried sediments of the Atlantic Coastal Plain. Geology, 18, 954-957.

Macklin S., Ellison R., Manning J., Farrant A. \& Lorenti L. (2012) Engineering geological characterisation of the Barzaman Formation, with reference to coastal Dubai, UAE. Bulletin of Engineering Geology and the Environment, 71, 1-19.

McBride E.F. (1974) Significance of color in red, green, purple, olive, brown, and gray beds of difunta group, northeastern Mexico. Journal of Sedimentary Research, 44, 760-773.

Micheels A., Bruch A.A., Uhl D., Utescher T. \& Mosbrugger V. (2007) A late Miocene climate model simulation with ECHAM4/ML and its quantitative validation with terrestrial proxy data. Palaeogeography, Palaeoclimatology, Palaeoecology, 253, 251-270.

Purser B.H. (1985) Coastal evaporite systems. Pp. 72-102 in: Hypersaline Ecosystems, Springer, Berlin, Heidelberg.

Rodgers D.W. \& Gunatilaka A. (2003) Bajada formation by monsoonal erosion of a subaerial forebulge,
Sultanate of Oman. Sedimentary Geology, 154, 127-146.

Singer A. (1979) Palygorskite in sediments: Detrital, diagenetic or neoformed - a critical review. Geologische Rundschau, 68, 996-1008.

Stanger G. (2005) A palaeo-hydrogeological model for arsenic contamination in southern and south-east Asia. Environmental Geochemistry and Health, 27, 359-368.

Styles M., Ellison R., Arkley S., Crowley Q.G., Farrant A., Goodenough K.M., McKervey J., Pharaoh T., Phillips E., Schofield D. \& Thomas R.J. (2006) The geology and geophysics of the United Arab Emirates, 2, Geology. The British Geological Survey, Nottingham, UK.

Vine P. (1996) Natural Emirates: Wildlife and Environment of the United Arab Emirates. Trident Press Ltd., Australia.

Zaaboub N., Abdeljaouad S. \& López-Galindo A. (2005) Origin of fibrous clays in Tunisian Paleogene continental deposits. Journal of African Earth Sciences, 43, 491-504. 